\title{
SUBSTRATE SUPPLY FOR CALCITE PRECIPITATION IN EMILIANIA HUXLEYI: ASSESSMENT OF DIFFERENT MODEL APPROACHES ${ }^{1}$
}

\author{
Lena-Maria Holtz, ${ }^{2}$ Silke Thoms \\ Alfred Wegener Institute for Polar and Marine Research, Biogeosciences, Am Handelshafen 12, Bremerhaven 27570, Germany
}

Gerald Langer

Department of Earth Sciences, Cambridge University, Downing St., Cambridge CB2 3EQ, UK

and Dieter A. Wolf-Gladrow

Alfred Wegener Institute for Polar and Marine Research, Biogeosciences, Am Handelshafen 12, Bremerhaven 27570, Germany

\begin{abstract}
Over the last four decades, different hypotheses of $\mathrm{Ca}^{2+}$ and dissolved inorganic carbon transport to the intracellular site of calcite precipitation have been put forth for Emiliania huxleyi (Lohmann) Hay $\&$ Mohler. The objective of this study was to assess these hypotheses by means of mathematical models. It is shown that a vesicle-based $\mathrm{Ca}^{2+}$ transport would require very high intravesicular $\mathrm{Ca}^{2+}$ concentrations, high vesicle fusion frequencies as well as a fast membrane recycling inside the cell. Furthermore, a kinetic model for the calcification compartment is presented that describes the internal chemical environment in terms of carbonate chemistry including calcite precipitation. Substrates for calcite precipitation are transported with different stoichiometries across the compartment membrane. As a result, the carbonate chemistry inside the compartment changes and hence influences the calcification rate. Moreover, the effect of carbonic anhydrase (CA) activity within the compartment is analyzed. One very promising model version is based on a $\mathrm{Ca}^{2+} / \mathrm{H}^{+}$antiport, $\mathrm{CO}_{2}$ diffusion, and a $\mathrm{CA}$ inside the calcification compartment. Another promising model version is based on an import of $\mathrm{Ca}^{2+}$ and $\mathrm{HCO}_{3}^{-}$and an export of $\mathrm{H}^{+}$.
\end{abstract}

Key index words: biomineralization; $\mathrm{Ca}^{2+}$ transport; Calcification; coccolith formation; coccolith vesicle

Abbreviations: A, surface area; CA, carbonic anhydrase; CAP, coccolith-associated polysaccharide; $\mathrm{C} i$, inorganic carbon; $\mathrm{CS}$, cytosol; $\mathrm{CV}$, calcifying/coccolith vesicle; DIC, dissolved inorganic carbon; ER, endoplasmic reticulum; $\mathrm{PCV}$, proto-CV; pER, peripheral ER; PIC, particulate inorganic carbon; RB, reticular body; SR, sarcoplasmic reticulum; S, salinity; TA, total alkalinity; V, volume; $\theta$, temperature

Coccolithophores are unicellular haptophyte algae, which surround themselves with elaborately

\footnotetext{
${ }^{1}$ Received 19 December 2011. Accepted 19 November 2012.

${ }^{2}$ Author for correspondence: e-mail: Lena-Maria.Holtz@awi.de.
}

crafted calcite platelets, the coccoliths. Today, coccolithophores are, besides foraminifera, the most productive group of open ocean calcifiers in terms of calcite export (Baumann et al. 2004). Calcifiers contribute to the biological carbon pump not only by producing particulate organic carbon, which subsequently sinks to deeper layers while being remineralized but also drive the so-called "carbonate pump" or "counter pump" via precipitation and dissolution of calcium carbonate $\left(\mathrm{CaCO}_{3}\right.$; Volk and Hoffert 1985): Precipitation of calcium carbonate decreases total alkalinity (TA) and dissolved inorganic carbon (DIC) within the surface layer in a 2:1 molar ratio, resulting in an increase of $\mathrm{CO}_{2}$ (Zeebe and Wolf-Gladrow 2001). Below the lysocline, TA and DIC increase due to the dissolution of $\mathrm{CaCO}_{3}$.

Although coccoliths are formed intracellularly inside so-called coccolith vesicles (CV; Wilbur and Watabe 1963, Probert et al. 2007), calcite precipitation is strongly affected by changing ocean carbonate chemistry. Understanding the calcification process is critical to understand why and how calcification is affected by future changes in ocean $\mathrm{pCO}_{2}$. A strong correlation between increasing seawater carbonate concentration and coccolith mass has been demonstrated for dominant coccolithophores of the present ocean and the last 40,000 years (Beaufort et al. 2011). In many culture experiments, the dependence of coccolithophore calcite production on seawater carbonate chemistry was examined. The results of these studies are partly discrepant (Hoppe et al. 2011 and references therein). Furthermore, Lohbeck et al. (2012) demonstrated the ability of Emiliania huxleyi cells to increase their calcite precipitation rate under high $\mathrm{pCO}_{2}$ via genetic adaptation. Hence, further investigations are needed to obtain a detailed understanding of the processes underlying calcite precipitation in coccolithophores.

The calcification process of two species, namely Pleurochrysis carterae and E. huxleyi, has been analyzed by means of cytobiological microscopy and physiological experiments. As for the cytological character- 
istics, there are three types of acidic polysaccharides in P. carterae named PS1, PS2, and PS3. The PS2 type is present in coccolithosomes and is capable of sequestering large amounts of $\mathrm{Ca}^{2+}$ (Marsh and Dickinson 1997). In contrast, E. huxleyi is lacking PS2 (Corstjens et al. 1998), but possesses one type of polysaccharide, the coccolith-associated polysaccharide (CAP, de Jong et al. 1976, Fichtinger-Schepman et al. 1981), which is probably not involved in $\mathrm{Ca}^{2+}$ transport but can influence crystal morphology by site-specific attachment to crystallographic steps (Henriksen et al. 2004). It is conspicuous that E. huxleyi features a so-called reticular body (RB), a labyrinthine membrane system, which is, at least during coccolith formation, connected to the CV (Klaveness 1972). In contrast, P. carterae lacks a RB and features transport vesicles containing so-called coccolithosomes. The latter are densely packed complexes of $\mathrm{Ca}^{2+}$ and acidic polysaccharides (Marsh 1994). It has been suggested that the RB in E. huxleyi, as opposed to the coccolithosomes in P. carterae, is involved in $\mathrm{Ca}^{2+}$ transport (Marsh and Dickinson 1997). The RB has a high surface to volume ratio and is therewith perfectly suited to import large amounts of $\mathrm{Ca}^{2+}$ from the cytosol across the membrane. Such a transmembrane transport of $\mathrm{Ca}^{2+}$ across the $\mathrm{CV}$ membrane (considering the $\mathrm{RB}$ as part of the CV) was first proposed by Klaveness (1976). This $\mathrm{Ca}^{2+}$ pathway, however, has the disadvantage that $\mathrm{Ca}^{2+}$ has to cross the cytosol, which is a low-Ca ${ }^{2+}$-compartment (Brownlee et al. 1995). Alternatively, it was suggested that $\mathrm{Ca}^{2+}$ is transported in vesicles to the $\mathrm{CV}$, the latter originating from the Golgi apparatus (Westbroek et al. 1984). Recently, this hypothesis was refined insofar that directly after entering the cytosol $\mathrm{Ca}^{2+}$ was assumed to be taken up by the peripheral endoplasmic reticulum (pER) (Berry et al. 2002, Brownlee and Taylor 2004), from which it travels via vesicles to the Golgi apparatus. Another possibility of $\mathrm{Ca}^{2+}$ entry into the cell is fluid phase endocytosis, which has been proposed for foraminifera (Erez 2003). Attempts to visualize fluid phase endocytosis in coccolithophores, however, have so far been unsuccessful (Berry et al. 2002).

It is at present not possible to test these different hypotheses of $\mathrm{Ca}^{2+}$ transport on the basis of observational data, and it might well take another decade or more before it will be. In the meantime, however, it is worthwhile to employ a theoretical means of judging different scenarios of cellular $\mathrm{Ca}^{2+}$ transport. In this study, we did so by performing some calculations concerning the pathway of $\mathrm{Ca}^{2+}$ through the cytosol, i.e., inside vesicles or directly through the cytosol. For the latter pathway we further implemented a kinetic model to investigate the influence of different membrane transporter stoichiometries on the carbonate chemistry inside the $\mathrm{CV}$, and hence on the calcite precipitation rate. E. huxleyi was chosen as the model species because it is one of the most productive coccolithophores in terms of calcite export (Baumann et al. 2004) and moreover one of the best-studied coccolithophores.

\section{METHODS}

Quantitative assessment of two major transport hypotheses for $\mathrm{Ca}^{2+}$. The two major hypotheses concerning the pathway of $\mathrm{Ca}^{2+}$ through the cytosol for E. huxleyi are a vesicle-based transport and a transport directly through the cytosol. Currently, a transport inside vesicles, where $\mathrm{Ca}^{2+}$ is shielded from the cytosol, is favored (Brownlee and Taylor 2004). For both transport hypotheses we will calculate in the following, how the provision with sufficient $\mathrm{Ca}^{2+}$ can be maintained.

Vesicle-based $\mathrm{Ca}^{2+}$ transport: First, the number of $\mathrm{Ca}^{2+}-$ transporting vesicles that is essential to match observed calcification rates will be determined for $E$. huxleyi. The results will then be compared to the corresponding values calculated for $P$. carterae, an alga that has been observed to transport $\mathrm{Ca}^{2+}$ toward the growing coccoliths by means of vesicles filled with coccolithosomes.

A full-size coccolith of E. huxleyi contains $\sim 22 \mathrm{fmol} \mathrm{Ca}^{2+}$ (Young and Ziveri 2000) and is built in about $1 \mathrm{~h}$ (Paasche 1962, Table 1). Based on these two constraints, hypothetical vesicle fusion frequencies can be calculated dependent on vesicle radius (cf. Fig. 1a). We consider three different $\left[\mathrm{Ca}^{2+}\right]$ for our calculations.

The first $\left[\mathrm{Ca}^{2+}\right]$ corresponds to the concentration found for another component of the endomembrane system $\left(0.5 \mathrm{mmol} \cdot \mathrm{L}^{-1}\right.$, Gussone et al. 2006) namely the endoplasmic reticulum (ER; solid line in Fig. 1, a and b). The maximum $\left[\mathrm{Ca}^{2+}\right]$ gradient across a membrane that can be accomplished by ATP hydrolysis is $10^{5}$ (Langer et al. 2006). Thus, the second calculation is based on a $\left[\mathrm{Ca}^{2+}\right]$ of $10 \mathrm{mmol} \cdot \mathrm{L}^{-1}\left(=10 \times\right.$ cytosolic $\left[\mathrm{Ca}^{2+}\right]$; dashed line $)$. Assuming $\mathrm{Ca}^{2+}$-binding molecules could further increase the $\left[\mathrm{Ca}^{2+}\right]$ by a factor of 100 (optimistic guess deduced from values given in Sze et al. 2000) leads to the third $\left[\mathrm{Ca}^{2+}\right]$ of $1 \mathrm{~mol} \cdot \mathrm{L}^{-1}$ (dotted line). The coccolithosomes of $P$. carterae have actually been found to exhibit $\mathrm{Ca}^{2+}$ concentrations of $6 \mathrm{~mol} \cdot \mathrm{L}^{-1}$ (van der Wal et al. 1983b). The polyanion PS2, however, which is most probably responsible for this extraordinarily strong $\mathrm{Ca}^{2+}$ accumulation, does not exist in E. huxleyi (Marsh and Dickinson 1997). The hypothetical $\mathrm{Ca}^{2+}$ transporting vesicles bring along biomembrane to the CV. The

TABLE 1. Constraints for vesicle-mediated $\mathrm{Ca}^{2+}$ transport in Emiliania huxleyi. $\mathrm{CV}=$ coccolith vesicle; $\mathrm{ER}=$ endoplasmic reticulum.

\begin{tabular}{|c|c|}
\hline Constraint & Value \\
\hline Coccolith formation time & 1 h (Paasche 1962) \\
\hline $\begin{array}{l}\mathrm{Ca}^{2+} \text { content of one full-size } \\
\text { coccolith with diameter of } \\
3.5 \mu \mathrm{m}\end{array}$ & $\begin{array}{l}22 \text { fmol (Young and Ziveri } \\
2000 \text { ) }\end{array}$ \\
\hline $\begin{array}{l}\text { Surface of one full-size CV } \\
\text { with diameter }=3.5 \mu \mathrm{m}\end{array}$ & $\begin{array}{l}33 \mu \mathrm{m}^{2} \text {, for calculation see } \\
\text { Appendix } \mathrm{S} 1\end{array}$ \\
\hline Free $\left[\mathrm{Ca}^{2+}\right]$ in ER & $\begin{array}{l}0.5 \mathrm{mmol} \cdot \mathrm{L}^{-1} \text { (Gussone } \\
\text { et al. } 2006)\end{array}$ \\
\hline Maximal free $\left[\mathrm{Ca}^{2+}\right]^{*}$ & $\begin{array}{l}10 \mathrm{mmol} \cdot \mathrm{L}^{-1} \text {, calculated } \\
\text { by Langer et al. (2006) }\end{array}$ \\
\hline High total $\left[\mathrm{Ca}^{2+}\right]^{* *}$ & $\begin{array}{l}1 \mathrm{~mol} \cdot \mathrm{L}^{-1} \text {, calculated, } \\
\text { see text }\end{array}$ \\
\hline $\begin{array}{l}\text { Observed vesicle radius in } \\
\text { calcifying cells of Emiliania } \\
\text { huxleyi }\end{array}$ & $\begin{array}{l}25 \mathrm{~nm} \text { (Westbroek et al. } \\
1984 \text { ) calculated, see text }\end{array}$ \\
\hline
\end{tabular}

*, Established by ATP hydrolysis.

**, Theoretical value. 

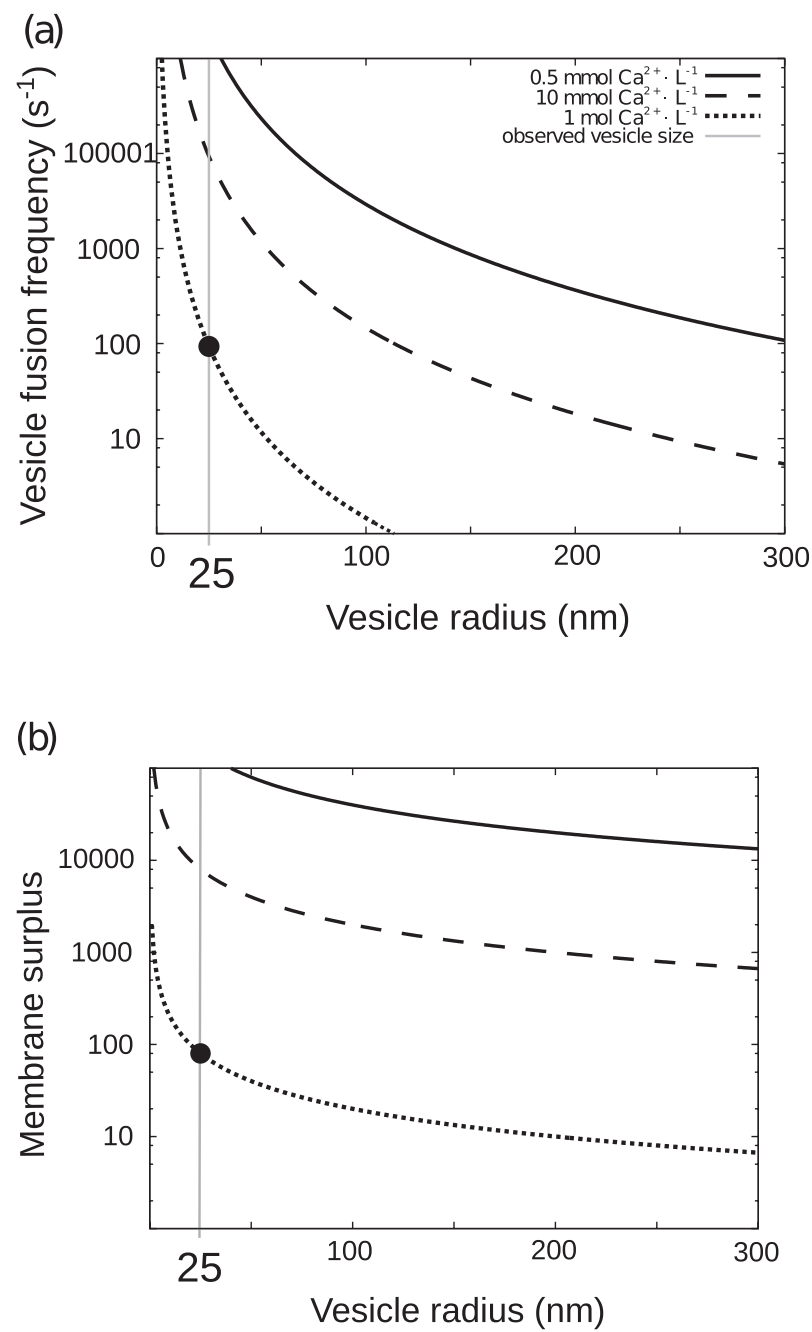

Fig. 1. Hypothetical vesicle fusion frequencies and the corresponding membrane surplus in dependence on different vesicle radii at three different $\left[\mathrm{Ca}^{2+}\right]$. (a) The vesicle fusion frequency that is essential to cover the demand of $\mathrm{Ca}^{2+}$ for coccolith synthesis is shown in dependence on the vesicle radius. (b) Amount of full-size CVs that could be formed by the membrane amount resulting from the vesicle fusion frequencies calculated for (a). Vesicles with a radius of $25 \mathrm{~nm}$ (typical radius of Golgi vesicles) have been observed in Emiliania huxleyi (cf. Fig. 4h in Westbroek et al. 1984; vertical line). The solid line indicates that a $\left[\mathrm{Ca}^{2+}\right]$ of $0.5 \mathrm{mmol} \cdot \mathrm{L}^{-1}$ inside the vesicles is presumed, the results presented by the dashed line are based on a $\left[\mathrm{Ca}^{2+}\right]$ of $10 \mathrm{mmol} \cdot \mathrm{L}^{-1}$. The dotted line presents the results based on a $\left[\mathrm{Ca}^{2+}\right]$ of $1 \mathrm{~mol} \cdot \mathrm{L}^{-1}$.

calculated vesicle flux (Fig. 1a) actually implies an excess membrane amount, which would have to be recycled during the time of coccolith formation. The corresponding excess membrane amount relative to the membrane amount required to cover one full-size coccolith is shown in Figure 1b.

The results presented in Figure 1, a and b summarize as follows: When considering the vesicle size that was observed in E. huxleyi (25 $\mathrm{nm}$ radius) and further presuming the high $\left[\mathrm{Ca}^{2+}\right]$ of $1 \mathrm{~mol} \cdot \mathrm{L}^{-1}, 93$ vesicles would have to fuse per second with the $\mathrm{CV}$ to cover the demand of $\mathrm{Ca}^{2+}$ for coccolith synthesis (marked intersection in Fig. 1a). Thereby, 80 times more membrane would be transported towards the CV than
TABLE 2. Vesicle transport-related values for Pleurochrysis carterae. CV stands for coccolith vesicle.

\begin{tabular}{lc}
\hline \hline Description & Value \\
\hline $\mathrm{Ca}^{2+}$ content of one & $3.3 \mathrm{fmol}$ (van der Wal \\
coccolith & et al. 1983b) \\
Coccolith formation time & $24 \mathrm{~min}$ (van der Wal \\
& et al. 1983b) \\
{$\left[\mathrm{Ca}^{2+}\right]$ of coccolithosomes } & $6 \mathrm{~mol} \cdot \mathrm{L}^{-1}$ (van der Wal \\
& et al. 1983b) \\
Vesicle radius & $200 \mathrm{~nm}$ (Fig. 19 in Outka \\
& and Williams 1971) \\
Vesicle surface & $0.5 \mu \mathrm{m}^{2}$, calculated \\
{$\left[\mathrm{Ca}^{2+}\right]$ in vesicles } & $0.6 \mathrm{~mol}^{-1} \mathrm{~L}^{-1}$ calculated \\
$\mathrm{Ca}^{2+}$ content of one vesicle & $21 \mathrm{amol}^{2}$ calculated \\
$\mathrm{CV}$ surface & $5 \mu \mathrm{m}^{2}$, calculated \\
\hline
\end{tabular}

is needed (marked intersection in Fig. 1b). Such high vesicle fusion frequencies and membrane recycling rates appear to be unrealistic, when studying the EM images of van der Wal et al. (1983a) and Westbroek et al. (1984). However, this argument cannot be used to strictly preclude a vesicle-based transport. Therefore, we will additionally calculate the equivalent values for $P$. carterae. In contrast with $E$. huxleyi, $P$. carterae forms about three coccoliths at once (see fig. 14 in Outka and Williams 1971). Hence, an overall fusion frequency of 0.3 vesicles $\cdot \mathrm{s}^{-1}$ can be deduced from the values given in Table 2 for $P$. carterae when assuming a vesicle radius of $200 \mathrm{~nm}$. Overall, 1.6 times as much membrane is transported toward the $\mathrm{CV}$ than is required for $\mathrm{CV}$ growth in $P$. carterae. This corresponds to recycling $0.4 \mu^{2}$ membrane per minute. By contrast, the hypothetical membrane surplus of E. huxleyi is 80 , corresponding to $43 \mu \mathrm{m}^{2} \cdot \mathrm{min}^{-1}$. Since the excess membrane area is most likely recycled inside the cell, it should be noted that E. huxleyi exhibits a 10-fold smaller cell volume than $P$. carterae.

Consequently, a vesicle-based $\mathrm{Ca}^{2+}$ transport in E. huxleyi would require high fusion frequencies as well as a high membrane surplus, even when presuming a $\left[\mathrm{Ca}^{2+}\right]$ of $1 \mathrm{~mol} \cdot \mathrm{L}^{-1}$ inside the vesicles. Please note that the overall calcificationrelated vesicle flux may actually be considerably higher than was calculated above when assuming a $\mathrm{Ca}^{2+}$ transport from the peripheral space into the endomembrane system (here: pER): As shown above, the vesicle flux can be minimized via a strong $\mathrm{Ca}^{2+}$ accumulation inside the vesicles. High $\left[\mathrm{Ca}^{2+}\right]$ $\left(>10 \mathrm{mmol} \cdot \mathrm{L}^{-1}\right)$ can be accomplished via $\mathrm{Ca}^{2+}$-binding molecules, which first have to reach the site of $\mathrm{Ca}^{2+}$ accumulation. A vesicle-based transport of these $\mathrm{Ca}^{2+}$-binding molecules would further increase the calcification-related vesicle flux.

$\mathrm{Ca}^{2+}$ provision directly through cytosol: Concerning the second transport hypothesis, it will be calculated, if enough $\mathrm{Ca}^{2+}$ can be made available via a transmembrane transport from the cytosol. The import of $\mathrm{Ca}^{2+}$ directly across the CV membrane is calculated by means of known kinetic values for $\mathrm{Ca}^{2+}$-ATPases (Table 3). $\mathrm{Ca}^{2+}$-ATPases are ATP-driven $\mathrm{Ca}^{2+} /$ $\mathrm{H}^{+}$exchangers of the sarcoplasmic reticulum (SR) membrane found in mammalian muscle cells that pump $\mathrm{Ca}^{2+}$ from the cytosol to the SR lumen with a molar stoichiometry of $2 \mathrm{Ca}^{2+}$ : 1 ATP : 2-3 $\mathrm{H}^{+}$(Møller et al. 2010). Expressed sequence tag clusters similar to those of $\mathrm{Ca}^{2+}$-ATPases have been located in E. huxleyi by von Dassow et al. (2009). According to the values given in Table 3 , up to $21 \mathrm{fmol} \mathrm{Ca}^{2+}$ can be provided for coccolith synthesis which comes close to the required $22 \mathrm{fmol} \mathrm{Ca}^{2+}$ (one complete coccolith).

A further possibility to import $\mathrm{Ca}^{2+}$ would be a temporally organized transport as proposed by Mackinder et al. (2010). 
TABLE 3. Values for hypothetical $\mathrm{Ca}^{2+}$ transporters in $\mathrm{CV}$ membrane. CV stands for coccolith vesicle, RB for reticular body. Please note that the temporal mean of the CV membrane is listed here, while Table 1 lists the value for a full-size CV.

\begin{tabular}{ll}
\hline \hline Description & \multicolumn{1}{c}{ Value } \\
\hline Transporter density & $6,355 \mu^{-2}($ Dulhunty et al. 1993) \\
Transport capacity & $20{\text { molecules } \mathrm{Ca}^{2+} \cdot}^{\text {transporter }} \cdot \mathrm{s}^{-1}$ \\
& (Bartolommei et al. 2006)
\end{tabular}

Temporal mean of CV membrane during coccolith formation $17 \mu \mathrm{m}^{2}$, for calculation see Appendix S1

RB membrane

$4-10 \mu \mathrm{m}^{2}$, calculated from TEM images given in van der Wal et al. (1983a)

Accumulated $\mathrm{Ca}^{2+} \quad 13 \mathrm{fmol}(\mathrm{CV})+3-8 \mathrm{fmol}(\mathrm{RB})$ after $1 \mathrm{~h}$

They suggest the establishment of a proton gradient across the membrane of a very early stage CV via a V-type ATPase. This proton gradient could then be used for the import of $\mathrm{Ca}^{2+}$ by means of proton gradient-driven $\mathrm{Ca}^{2+} / \mathrm{H}^{+}$exchangers. Both, V-type ATPases as well as the $\mathrm{Ca}^{2+} / \mathrm{H}^{+}$exchangers (CAX) are up-regulated in calcifying cells of E. huxleyi (Mackinder et al. 2011). Deactivating the V-type ATPase would lower the proton concentration inside the $\mathrm{CV}$, and calcite could be precipitated. At this stage, most of the $\mathrm{Ca}^{2+}$ should already be accumulated inside the $\mathrm{CV}$ because $\mathrm{Ca}^{2+}$ import is driven by the proton gradient from the CV to the cytosol, which cannot be sustained during calcite precipitation. We assume that this stage was the one presented in Figure $4 \mathrm{~d}$ in Westbroek et al. (1984), where the CV contains the first detectable part of the coccolith, the so-called proto-coccolith (Young and Westbroek 1991). Thus, a $\left[\mathrm{Ca}^{2+}\right]$ of $44 \mathrm{~mol} \cdot \mathrm{L}^{-1}$ would be necessary to accumulate $22 \mathrm{fmol} \mathrm{Ca}^{2+}$ (one complete coccolith). This concentration is unrealistically high because it exceeds the concentration of solid phase calcium (39 $\mathrm{mol} \cdot \mathrm{L}^{-1}$, Mortimer 2003). Furthermore, the described mechanism requires more ATP than importing $\mathrm{Ca}^{2+}$ by means of $\mathrm{Ca}^{2+}$-ATPases: proton-pumping ATPases can transport two protons by means of one ATP (Bennett and Spanswick 1984). When further assuming a stoichiometry of 1 $\mathrm{Ca}^{2+}: 3 \mathrm{H}^{+}$as stated in Sze et al. (2000) for the $\mathrm{Ca}^{2+} / \mathrm{H}^{+}$ exchanger (CAX), the import of one $\mathrm{Ca}^{2+}$ would cost 1.5 ATP. $\mathrm{Ca}^{2+}$-ATPases, in contrast, transfer one $\mathrm{Ca}^{2+}$ by means of 0.5 ATP (Møller et al. 2010).

All in all, the temporally organized import of $\mathrm{Ca}^{2+}$ that was proposed by Mackinder et al. (2010) is rather unlikely because the $\mathrm{Ca}^{2+}$ required for coccolith formation cannot be accumulated before the onset of calcite precipitation. A continuous transport, in contrast, can be accomplished according to our calculations. The major argument against this hypothesis concerns the diffusive $\mathrm{Ca}^{2+}$ supply through the low- $\left[\mathrm{Ca}^{2+}\right]$ environment of the cytosol. ATP-driven $\mathrm{Ca}^{2+}$ transporters generally exhibit high affinities towards $\mathrm{Ca}^{2+}(\mathrm{K}=0.1-2 \mu \mathrm{M})$, albeit having low transport capacities (Sze et al. 2000). The latter value could probably be increased via the number of transporters. Hence, enough $\mathrm{Ca}^{2+}$ could be taken up from the low- $\left[\mathrm{Ca}^{2+}\right]$ cytosol, if the diffusion velocity of $\mathrm{Ca}^{2+}$ through the cytosol was high enough. This velocity value can currently not be calculated because the putative pathway of $\mathrm{Ca}^{2+}$ through the cytosol remains unclear. TEM images of van der Wal et al. (1985) hint at high $\left[\mathrm{Ca}^{2+}\right]$ at various intra- cellular sites in noncalcifying S-type cells of E. huxleyi. Assuming the $\mathrm{Ca}^{2+}$ distribution was the same in calcifying cells and the $\mathrm{CV}$ could come close to, for instance, the peripheral space or to the tips of the chloroplast, $\mathrm{Ca}^{2+}$ transporters could, at least partly, face high $\left[\mathrm{Ca}^{2+}\right]$. Finally, we would like to add that, if the hypothetical $\mathrm{Ca}^{2+}$-transporting vesicles discussed above were filled at the Golgi apparatus, the question concerning the $\mathrm{Ca}^{2+}$ pathway through the cytosol arises again.

After all, more research is required to finally decide about the two hypotheses. On the one hand, the hypothetical $\mathrm{Ca}^{2+}$ transporting vesicles should be searched after, whereas on the other hand, the intracellular $\mathrm{Ca}^{2+}$ distribution is essential to elucidate. Furthermore, molecules with very high $\mathrm{Ca}^{2+}$ binding capacities should be searched after. However, according to our calculations, a continuous $\mathrm{Ca}^{2+}$ supply through the cytosol is the more likely hypothesis.

Kinetic model setup. In this kinetic model approach, the substrates for calcite precipitation are imported from the cytosol into the $\mathrm{CV}$ with different stoichiometries. Thereby, internal carbonate chemistry and hence calcite precipitation rate are influenced differently. The carbonate system inside the cytosol is assumed to be in chemical equilibrium. Inside the $\mathrm{CV}$, it is dynamic and modeled according to the reactions given by Zeebe and Wolf-Gladrow (2001). Size and morphology of the CV are estimated from EM images as described in Appendix S1. Surface area and volume of the CV were calculated to be $17 \mu \mathrm{m}^{2}$ and $1.6 \mu \mathrm{m}^{3}$, respectively. Calcite precipitation inside the CV is described according to the kinetics given by Zuddas and Mucci (1994). $\mathrm{CO}_{2}$ diffuses across the CV membrane in all model versions. The active transport of molecules across the CV membrane follows Michaelis-Menten kinetics except for proton-pumping ATPases, for which a constant transport rate is assumed. Detailed information concerning the model setup (Fig. 2) is given in Appendix S1.

We consider seven model versions (Fig. 3), which will be described in the following in more detail.

Model version I: $\mathrm{Ca}^{2+} / 2 \mathrm{H}^{+}$antiport: Dissolved inorganic carbon for calcite precipitation is derived exclusively from cytosolic $\mathrm{CO}_{2}$ that diffuses into the CV. Import of $\mathrm{Ca}^{2+}$ into the $\mathrm{CV}$ is carried out via a $1 \mathrm{Ca}^{2+} / 2 \mathrm{H}^{+}$exchanger. Model version $\mathrm{I}$ is divided into three subversions (Fig. 3), where Ia is based on a cytosolic DIC of $2 \mathrm{mmol} \cdot \mathrm{L}^{-1}$ and Ib on a cytosolic DIC of $55 \mathrm{mmol} \cdot \mathrm{L}^{-1}$. Version Ic rests upon a cytosolic DIC of $2 \mathrm{mmol} \cdot \mathrm{L}^{-1}$ and a carbonic anhydrase (CA) inside the CV.

Model version II: $\mathrm{Ca}^{2+} / 2 \mathrm{H}^{+}$antiport with active $\mathrm{CO}_{2}$ import: An active transport of $\mathrm{CO}_{2}$ into the $\mathrm{CV}$ is examined in addi-

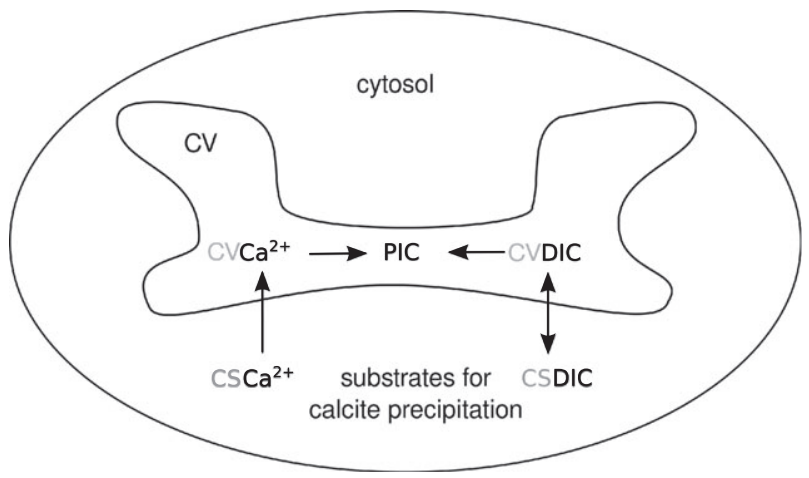

FIG. 2. Kinetic model setup. The coccolith veside (CV) is embedded inside the cytosol (CS). The substrates for calcite precipitation, $\mathrm{Ca}^{2+}$ and DIC, cross the membrane of the CV. Within the $\mathrm{CV}$, calcite (PIC) is precipitated. 


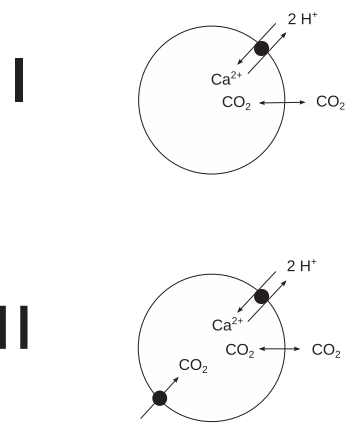

(a) $\mathrm{DIC}_{\mathrm{CS}}=2 \mathrm{mmol} \cdot \mathrm{L}^{-1}$ (b) $\mathrm{DIC}_{\mathrm{CS}}=55 \mathrm{mmol} \cdot \mathrm{L}^{-1}$ (c) $\mathrm{DIC}_{\mathrm{CS}}=2 \mathrm{mmol} \cdot \mathrm{L}^{-1}$, $\mathrm{CA}$ in $\mathrm{CV}$
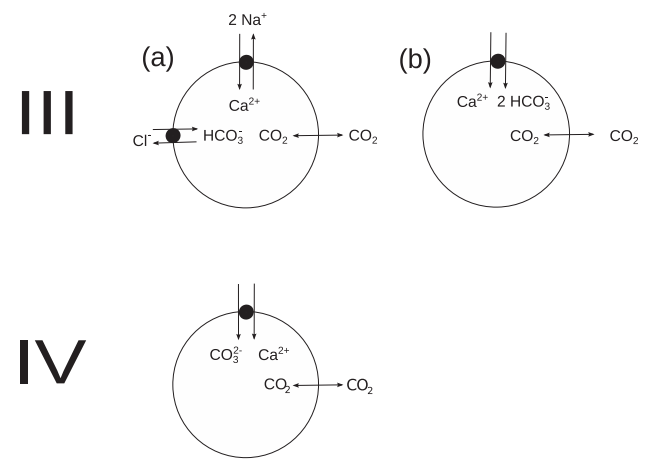

(a)
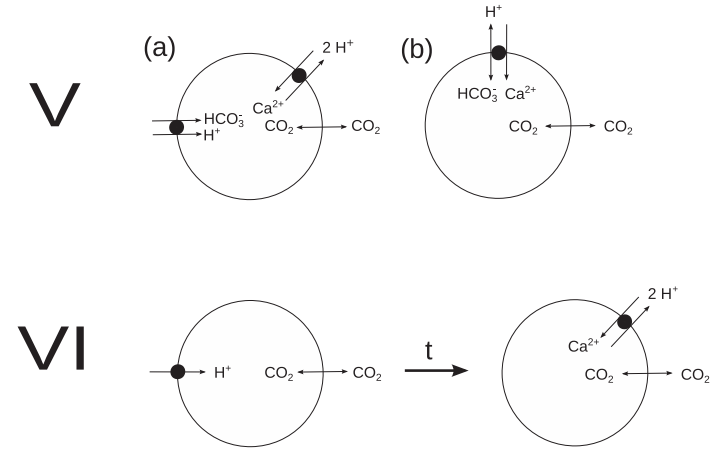

VII

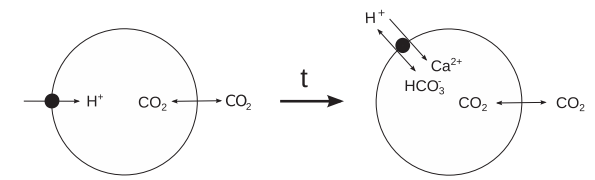

FIG. 3. Simplified drawing of model versions I to VII, where different substrates cross the CV membrane. Simple arrows indicate the diffusion of a substrate, whereas arrows with a filled circle indicate an active transport. The CV is depicted as a sphere for reasons of simplicity. For our calculations, a more complex shape of the CV was assumed as described in Appendix S1.

tion to the fluxes described by model version Ia. An active uptake of $\mathrm{CO}_{2}$ into the cell was proposed for green algae (Sültemeyer et al. 1989), cyanobacteria (Espie et al. 1989), as well as for E. huxleyi (Schulz et al. 2007).

Model version III: Import of $\mathrm{Ca}^{2+}$ and $\mathrm{HCO}_{3}^{-}$: Two model alternatives are introduced, in which $\mathrm{Ca}^{2+}$ and $\mathrm{HCO}_{3}^{-}$are imported into the CV. In IIIa, a $\mathrm{Ca}^{2+} / 2 \mathrm{Na}^{+}$and $\mathrm{a} \mathrm{HCO}_{3}^{-} /$ $\mathrm{Cl}^{-}$exchanger are inserted into the CV membrane based on reports of such transporters in E. huxleyi (Mackinder et al. 2010). IIIb considers a $\mathrm{Ca}^{2+} / 2 \quad \mathrm{HCO}_{3}^{-}$symporter. Similar transporters are known from cyanobacteria (Koropatkin et al. 2007) and mammals (Girijashanker et al. 2008).

Model version IV: $\mathrm{Ca}^{2+} / \mathrm{CO}_{3}^{2-}$ symport: $\mathrm{Ca}^{2+}$ and $\mathrm{CO}_{3}^{2-}$ are cotransported into the $\mathrm{CV}$ with a stoichiometry of $1: 1$. $\mathrm{Ca}^{2+}$ and $\mathrm{CO}_{3}^{2-}$ can assumingly not be cotransported without a substance that inhibits precipitation. Nevertheless, we here refer to this possibility.

Model version $\mathrm{V}: \mathrm{Ca}^{2+}$ and $\mathrm{HCO}_{3}^{-}$import and $\mathrm{H}^{+}$export: Two different transport mechanisms are introduced which potentially lead to the same stoichiometry of transported substrates: One $\mathrm{Ca}^{2+}$ and one $\mathrm{HCO}_{3}^{-}$are imported, while one $\mathrm{H}^{+}$is exported from the CV. This stoichiometry considers the deprotonation of $\mathrm{HCO}_{3}^{-}$to $\mathrm{CO}_{3}^{2-}$ for the formation of calcite, where the evolving $\mathrm{H}^{+}$is exported from the CV. Taylor et al. (2011) noticed that the evolving $\mathrm{H}^{+}$has to be exported from the whole cell to prevent internal acidification. Model version $\mathrm{Va}$ is based on a transport mechanism consisting of two decoupled transporters namely a $\mathrm{Ca}^{2+} / 2 \mathrm{H}^{+}$antiporter and a $\mathrm{HCO}_{3}^{-} / \mathrm{H}^{+}$symporter. $\mathrm{Ca}^{2+} / 2 \mathrm{H}^{+}$antiporters are known from literature, while the existence of $\mathrm{HCO}_{3}{ }^{-} / \mathrm{H}^{+}$symporters has been suggested (Staal et al. 1989). Bicarbonate ions and protons could also be imported via a $\mathrm{Na}^{+} / \mathrm{HCO}_{3}^{-}$symporter and a $\mathrm{Na}^{+} / \mathrm{H}^{+}$antiporter. Both transporters exist. Another possi- bility is one complex $\mathrm{Ca}^{2+} / \mathrm{HCO}_{3}^{-} / \mathrm{H}^{+}$transporter $(\mathrm{Vb})$ which is hypothetical.

Model version VI: $\mathrm{Ca}^{2+} / \mathrm{H}^{+}$exchange after import of $\mathrm{H}^{+}$: Inspired by the idea of a temporally organized ion transport (Mackinder et al. 2010), we divided model version VI into two phases: First, the establishment of a proton gradient, which is then used for the import of $\mathrm{Ca}^{2+}$ during coccolith formation. Gene expression of V-type ATPase subunits in E. huxleyi was found by von Dassow et al. (2009), and Corstjens et al. (2001) located a V-type ATPase in the membrane of the CV of $P$. carterae. Proton concentration gradient-driven $\mathrm{Ca}^{2+} / \mathrm{H}^{+}$exchangers in E. huxleyi were found by Mackinder et al. (2011).

Model version VII: $\mathrm{Ca}^{2+} / \mathrm{HCO}_{3}^{-}$import and $\mathrm{H}^{+}$export after import of $\mathrm{H}^{+}$: Bearing the previous model version in mind, we here use the generated proton gradient more efficiently by employing the complex transporter of model version $\mathrm{Vb}$ for the second phase.

\section{RESULTS AND DISCUSSION}

In the section, Quantitative assessment of two major transport hypotheses for $\mathrm{Ca}^{2+}$, the two major hypotheses for $\mathrm{Ca}^{2+}$ transport through the cytosol were assessed. According to our calculations, a transport directly through the cytosol is more likely than a vesiclebased transport. Therefore, we based the kinetic model approach on a $\mathrm{Ca}^{2+}$ transport directly through the cytosol. The equations that describe carbonate chemistry and $\left[\mathrm{Ca}^{2+}\right]$ in the kinetic model (see Appendix S1) were numerically integrated until steady state was obtained. These steady 


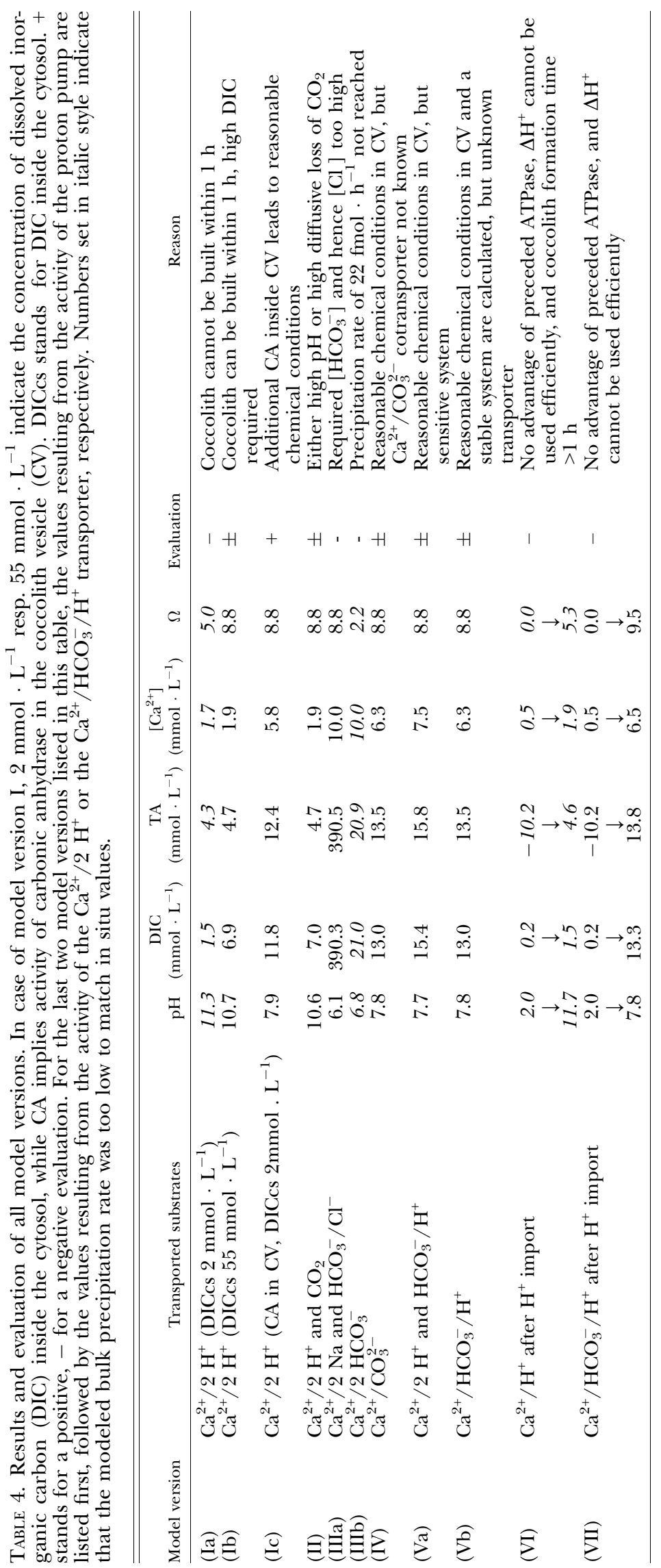


state values as well as an evaluation of all model versions are given in Table 4 . We further show the time-dependent development of DIC, TA, $\mathrm{pH}$, the individual $\mathrm{C}$ species, $\Omega$, and $\left[\mathrm{Ca}^{2+}\right]$ for model version Ic (Fig. 4) as representative for what the kinetic model provides. For all other model versions, the
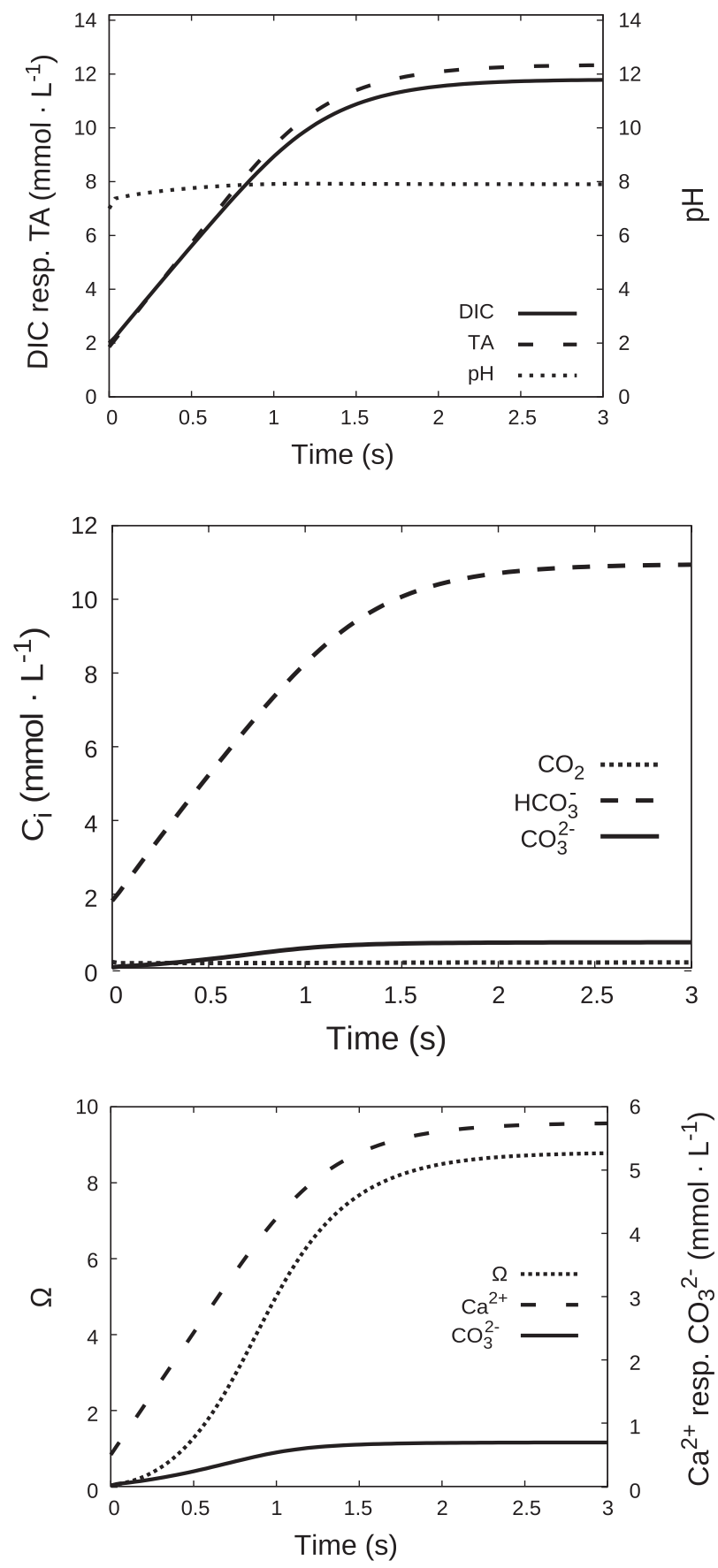

FIG. 4. The time-dependent evolution of dissolved inorganic carbon (DIC), total alkalinity (TA), pH, $\left[\mathrm{CO}_{2}\right], \quad\left[\mathrm{HCO}_{3}^{-}\right]$, $\left[\mathrm{CO}_{3}^{2-}\right], \Omega$, and $\left[\mathrm{Ca}^{2+}\right]$ inside the $\mathrm{CV}$ are presented for model version Ic, where a carbonic anhydrase (CA) is inside the CV. At Time $=0 \mathrm{~s}$, the preset initial conditions are active given. During the presented time regime, the modeled state variables approach the steady state values listed in Table 4 . corresponding figures are given in Appendix S1 (Fig. S1-S5).

In the following, we will discuss the question whether specific transport scenarios (model versions I to VII; Fig. 3) are feasible in terms of carbonate chemistry inside the CV. The different model versions are characterized by the substrates that are transported across the CV membrane. The only feature all versions have in common is the transport of $\mathrm{Ca}^{2+}$ into the $\mathrm{CV}$ and a diffusion of $\mathrm{CO}_{2}$ across the $\mathrm{CV}$ membrane.

Model version $\mathrm{I}$ is based on a $\mathrm{Ca}^{2+} / 2 \mathrm{H}^{+}$exchanger. In version Ia, the proton concentration inside the CV was too low to support the calcium flux that is essential to match the observed precipitation rate of calcite.

In version $\mathrm{Ib}$, where a cytosolic DIC concentration of $55 \mathrm{mmol} \cdot \mathrm{L}^{-1}$ is assumed, the in situ calcite precipitation rate is reached. The presumed high cytosolic DIC concentration may be accomplished by a $\mathrm{Cl}^{-} / \mathrm{HCO}_{3}^{-}$exchanger located in the plasma membrane. Interestingly, such a transporter (of SLC4 family) was shown to be specific for diploid, hence calcifying cells of E. huxleyi (von Dassow et al. 2009). Its up-regulation correlates with calcification (Mackinder et al. 2011). The cytosolic DIC has, however, not yet been measured. When roughly estimating the cytosolic volume of $E$. huxleyi to constitute $1 / 10$ of the whole-cell volume, $55 \mathrm{mmol} \cdot \mathrm{L}^{-1}$ DIC could be easily accumulated in the cytosol when presuming the cellular bulk DIC of $13 \mathrm{mmol} \cdot \mathrm{L}^{-1}$ measured by Sekino and Shiraiwa (1994). Furthermore, version Ib features a very high $\Delta \mathrm{pH}$ of almost four across the CV membrane, where the steepest $\mathrm{pH}$ gradient known to us is $\sim 3-3.5$ (Sitte et al. 2002) across the thylakoid membrane. However, the existence of a $\mathrm{pH}$ gradient steeper than that cannot be ruled out.

The energy-dependent accumulation of DIC inside the cytosol needed in version Ib can be overcome when assuming CA activity inside the CV (version Ic). This option was proposed by Soto et al. (2006) and a contribution of CA to calcification was suggested on the basis of genetic data (Soto et al. 2006, Richier et al. 2009).

To sum up, model version I provides realistic scenarios and ATP-driven $\mathrm{Ca}^{2+} / \mathrm{H}^{+}$exchangers as well as the enzyme carbonic anhydrase have already been discovered in calcifying $E$. huxleyi.

Model version II features a $1 \mathrm{Ca}^{2+} / 2 \mathrm{H}^{+}$exchange and an active $\mathrm{CO}_{2}$ import into the $\mathrm{CV}$. The resulting $\mathrm{pH}$ of 10.6 (Table 4) is high, but can be lowered when further increasing the import rate of $\mathrm{CO}_{2}$ : An elevation of $\mathrm{V}_{\max (\mathrm{CO} 2)}$ from $1.4 \mathrm{fmol} \cdot \mathrm{s}^{-1}$ to $16 \mathrm{fmol} \cdot \mathrm{s}^{-1}$ leads to a $\mathrm{pH}$ of about 9 and a $\left[\mathrm{CO}_{2}\right]$ of $52 \mathrm{mmol} \cdot \mathrm{L}^{-1}$. The $\mathrm{V}_{\max (\mathrm{CO})}$ listed in Table 4 (gross value) is actually already 350-fold higher than the net $\mathrm{V}_{\max (\mathrm{CO} 2)}$ given by Schulz et al. (2007). The gross $\mathrm{V}_{\max (\mathrm{CO} 2)}$, however, has not been determined. Concerning the high $\left[\mathrm{CO}_{2}\right]$, maximum rates for the diffusive $\mathrm{CO}_{2}$ efflux from the $\mathrm{CV}$ will certainly be induced. A considerable $\mathrm{CO}_{2}$ leakage, 
however, is a well-known phenomenon in algae (Kranz et al. 2009).

To conclude, the in situ precipitation rate can be matched. However, model version II is probably less energy efficient than model version Ic.

Model version IIIa features $\mathrm{Ca}^{2+} / 2 \mathrm{Na}^{+}$and $\mathrm{HCO}_{3}^{-} / \mathrm{Cl}^{-}$transporters, whereas version IIIb is characterized by a $\mathrm{Ca}^{2+} / 2 \mathrm{HCO}_{3}^{-}$transporter. The $\left[\mathrm{HCO}_{3}{ }^{-}\right]$and $\left[\mathrm{Cl}^{-}\right]$that are required inside the $\mathrm{CV}$ in model version IIIa are unrealistically high. In version IIIb, in contrast, bulk precipitation rate was too low to match the in situ value because the imported $\mathrm{HCO}_{3}^{-}$(two per $\mathrm{Ca}^{2+}$ ) shift the carbonate system toward $\mathrm{HCO}_{3}^{-}$and $\mathrm{CO}_{2}$. Hence, the $\left[\mathrm{CO}_{3}^{2-}\right]$ and $\Omega$ are too low to support the required calcite precipitation rate. In summary, both subversions were shown to be unrealistic.

Version IV features a $\mathrm{Ca}^{2+} / \mathrm{CO}_{3}^{2-}$ symporter. The only shortcoming of this version is that such a transporter has so far not been found.

In version $\mathrm{Va}$, the import of $\mathrm{Ca}^{2+}$ and $\mathrm{HCO}_{3}^{-}$is accomplished by two transporters namely a $\mathrm{Ca}^{2+} / 2$ $\mathrm{H}^{+}$antiporter and a $\mathrm{HCO}_{3}^{-} / \mathrm{H}^{+}$symporter. The shortcoming of this version is the required fine tuning of the rates of these two transporters: The $\mathrm{pH}$ value inside the $\mathrm{CV}$ drops when the $\mathrm{Ca}^{2+} / 2 \mathrm{H}^{+}$antiport decreases slightly and the $\mathrm{HCO}_{3}^{-} / \mathrm{H}^{+}$symport increases slightly, respectively. In both cases, the precipitation rate is lowered. This problem can be over come when assuming one $\mathrm{Ca}^{2+} / \mathrm{HCO}_{3}^{-} / \mathrm{H}^{+}$cotransporter (version $\mathrm{Vb}$ ). The latter is hypothetical, but so is the $\mathrm{HCO}_{3}^{-} / \mathrm{H}^{+}$symporter of version $\mathrm{Va}$. The outputs of both model versions ( $\mathrm{Va}$ and $\mathrm{Vb}$ ) are very similar to the outputs of version IV due to the fast conversion between $\mathrm{HCO}_{3}^{-}$and $\mathrm{CO}_{3}^{2-}$.

Versions VI and VII are based on a temporally organized ion transport similar to the import mechanism proposed by Mackinder et al. (2010). First, a $\mathrm{H}^{+}$gradient across the CV membrane is established, which is subsequently used to drive the import of $\mathrm{Ca}^{2+}$. We distinguished a version featuring a $\mathbf{C a}^{2+} / \mathbf{H}^{+}$exchanger (version VI), and one featuring a $\mathbf{C a}^{2+} / \mathbf{H C O}_{3}^{-} / \mathbf{H}^{+}$cotransporter (version VII). Briefly, neither version is realistic because the time period in which the $\mathrm{H}^{+}$gradient is used is too short ( 1 s). Nevertheless, Mackinder et al. (2011) found genes of a $\mathrm{Ca}^{2+} / \mathrm{H}^{+}$exchanger belonging to the CAX family and a vacuolar $\mathrm{H}^{+}$-ATPase to be up-regulated in calcifying E. huxleyi cells. An alternative to use these two transporters was a continuous import of $\mathrm{Ca}^{2+}$ by means of a localized proton gradient across the CV membrane, where the protons would have to be shielded from the growing coccolith. Unfortunately, this hypothesis can currently not be assessed.

\section{CONCLUSION}

We used model approaches to assess different possibilities of $\mathrm{Ca}^{2+}$ import into the $\mathrm{CV}$. It was shown that continuous $\mathrm{Ca}^{2+}$ import via membrane transporters during coccolith formation is the most likely scenario. Alternative scenarios such as vesiclebased $\mathrm{Ca}^{2+}$ transport or the formation of a $\mathrm{Ca}^{2+}$ pool were dismissed.

The impact of different transporter stoichiometries to import $\mathrm{Ca}^{2+}$ and $\mathrm{C} i$ into the $\mathrm{CV}$ was studied by means of a kinetic model. As for an overall assessment of the different model versions, the one based on a $\mathrm{CV}$-internal $\mathrm{CA}$, a $\mathrm{Ca}^{2+} / \mathrm{H}^{+}$exchanger, and a supply of $\mathrm{C} i$ exclusively via $\mathrm{CO}_{2}$ diffusion (Ic) can be regarded as the most promising one because the required $\mathrm{CA}$ as well as $\mathrm{Ca}^{2+} / \mathrm{H}^{+}$exchangers have already been discovered in E. huxleyi.

Alternative versions based on a $\mathrm{Ca}^{2+} / \mathrm{CO}_{3}^{2-}$ symport (IV) and a $\mathrm{Ca}^{2+} / \mathrm{HCO}_{3}^{-} / \mathrm{H}^{+}$antiport (V) are also feasible in terms of our model, but the respective transporters have not been discovered yet.

We thank Judith Hauck, Dörte Burhop, and especially Sebastian Rokitta for many helpful comments on the manuscript. Furthermore, we want to thank four anonymous reviewers who helped to improve the manuscript. This work was supported by the European Commission through grant 211384 (EU FP7 "EPOCA"). Financial support for BIOACID was provided by the German Federal Ministry of Education and Research (BMBF, FKZ 03F0608). The research leading to these results has received funding from the European Community's Seventh Framework Programme under grant agreement 265103 (Project MedSeA). This work was funded in part by The European Research Council (ERC grant 2010NEWLOG ADG-267931 HE).

\section{REFERENCES}

Bartolommei, G., Tadini-Buoninsegni, F., Hua, S., Moncelli, M. R., Inesi, G. \& Guidelli, R. 2006. Clotrimazole inhibits the $\mathrm{Ca}^{2+}$-ATPase (SERCA) by interfering with $\mathrm{Ca}^{2+}$ binding and favoring the E2 conformation. J. Biol. Chem. 281:9547-51.

Baumann, K. -H., Böckel, B. \& Frenz, M. 2004. Contribution of coccolithophorids to the carbonate budget of South Atlantic surface sediments. In Thierstein Hans, R. \& Young Jeremy, R. [Eds.] Coccolithophores - From Molecular Processes to Global Impact. Springer, Berlin Heidelberg, pp. 367-402.

Beaufort, L., Probert, I., de Garidel-Thoron, T., Bendif, E. M., Ruiz-Pino, D., Metzl, N., Goyet, C. et al. 2011. Sensitivity of coccolithophores to carbonate chemistry and ocean acidification. Nature 476:80-3.

Bennett, A. B. \& Spanswick, R. M. 1984. H'-ATPase activity from storage tissue of Beta vulgaris. Plant Physiol. 74:545-8.

Berry, L., Taylor, A. R., Lucken, U., Ryan, K. P. \& Brownlee, C. 2002. Calcification and inorganic carbon acquisition in $\mathrm{coc}-$ colithophores. Funct. Plant Biol. 29:289-99.

Brownlee, C., Davies, M., Nimer, N., Dong, L. F. \& Merrett, M. J. 1995. Calcification, photosynthesis and intracellular regulation in Emiliania huxleyi. Bulletin de l'Institut océanographique 14:19-35.

Brownlee, C. \& Taylor, A. 2004. Calcification in coccolithophores: a cellular perspective. In Thierstein Hans, R. \& Young Jeremy, R. [Eds.] Coccolithophores - From Molecular Processes to Global Impact. Springer, Berlin Heidelberg, pp. 31-49.

Corstjens, P. L. A. M., Araki, Y. \& Gonzalez, E. L. 2001. A coccolithophorid calcifying vesicle with a vacuolar-type ATPase proton pump: cloning and immunolocalization of the $\mathrm{V}$ subunit c. J. Phycol. 37:71-8.

Corstjens, P. L. A. M., Van Der Kooij, A., Linschooten, C., Brouwers, G. J., Westbroek, P. \& Jong, E. W. 1998. GPA, a calcium- 
binding protein in the coccolithophorid Emiliania huxleyi (Prymnesiophyceae). J. Phycol. 34:622-30.

von Dassow, P., Ogata, H., Probert, I., Wincker, P., Da Silva, C., Audic, S., Claverie, J.-M. \& de Vargas, C. 2009. Transcriptom$\mathrm{e}$ analysis of functional differentiation between haploid and diploid cells of Emiliania huxleyi, a globally significant photosynthetic calcifying cell. Genome Biol. 10: R114.1-114.33.

Dulhunty, A. F., Junankar, P. R. \& Stanhope, C. 1993. Immunogold labeling of calcium ATPase in sarcoplasmic reticulum of skeletal muscle: use of 1-nm, 5-nm, and 10-nm gold. J. Histochem. Cytochem. 41:1459-66.

Erez, J. 2003. The source of ions for biomineralization in foraminifera and their implications for paleoceanographic proxies. Dove, P., De Yoreo, J. J. \& Weiner, S. [Eds.] Biomineralization, vol. 54. Mineralogical society of America/Geochemical society, Washington, pp. 115-49.

Espie, G. S., Miller, A. G. \& Canvin, D. T. 1989. Selective and reversible inhibition of active $\mathrm{CO}_{2}$ transport by hydrogen sulfide in a cyanobacterium. Plant Physiol. 91:387-94.

Fichtinger-Schepman, A. M. J., Kamerling, J. P., Versluis, C. \& Vliegenthart, J. F. G. 1981. Structural studies of the methylated, acidic polysaccharide associated with coccoliths of Emiliania huxleyi (Lohmann) Kamptner. Carbohyd. Res. 93:105-23.

Girijashanker, K., He, L., Soleimani, M., Reed, J. M., Li, H., Liu, Z., Wang, B., Dalton, T. P. \& Nebert, D. W. 2008. Slc39a14 gene encodes ZIP14, a metal/bicarbonate symporter: similarities to the ZIP8 transporter. Mol. Pharmacol. 73:1413-23.

Gussone, N., Langer, G., Thoms, S., Nehrke, G., Eisenhauer, A., Riebesell, U. \& Wefer, G. 2006. Cellular calcium pathways and isotope fractionation in Emiliania huxleyi. Geology 34:62528.

Henriksen, K., Stipp, S. L. S., Young, J. R. \& Marsh, M. E. 2004. Biological control on calcite crystallization: AFM investigation of coccolith polysaccharide function. Am. Mineral. $89: 1586-96$.

Hoppe, C. J. M., Langer, G. \& Rost, B. 2011. Emiliania huxleyi shows identical responses to elevated $\mathrm{pCO}_{2}$ in TA and DIC manipulations. J. Exp. Mar. Biol. Ecol. 406:54-62.

de Jong, E. W., Bosch, L. \& Westbroek, P. 1976. Isolation and characterization of a $\mathrm{Ca}^{2+}$-binding polysaccharide associated with coccoliths of Emiliania huxleyi (Lohmann) Kamptner. Eur. J. Biochem. 70:611-21.

Klaveness, D. 1972. Coccolithus huxleyi (Lohmann) Kamptner. 1. Morphological investigations on the vegetative cell and the process of coccolith formation. Protistologica 8:335-46.

Klaveness, D. 1976. Emiliania huxleyi (Lohmann) Hay and Mohler. III. mineral deposition and the origin of the matrix during coccolith formation. Protistologica 12:217-24.

Koropatkin, N. M., Koppenaal, D. W., Pakrasi, H. B. \& Smith, T. J. 2007. The structure of a cyanobacterial bicarbonate transport protein. CmpA. J. Biol. Chem. 282:2606-14.

Kranz, S. A., Sültemeyer, D., Richter, K. U. \& Rost, B. 2009. Carbon acquisition by Trichodesmium: the effect of $\mathrm{pCO}_{2}$ and diurnal changes. Limnol. Oceanogr. 54:548-59.

Langer, G., Gussone, N., Nehrke, G., Riebesell, U., Eisenhauer, A., Kuhnert, H., Rost, B., Trimborn, S. \& Thoms, S. 2006. Coccolith strontium to calcium ratios in Emiliania huxleyi: the dependence on seawater strontium and calcium concentrations. Limnol. Oceanogr. 51:310-20.

Lohbeck, K. T., Riebesell, U. \& Reusch, T. B. H. 2012. Adaptive evolution of a key phytoplankton species to ocean acidification. Nature Geosci. doi:10.1038/ngeo1441.

Mackinder, L., Wheeler, G., Schroeder, D., Riebesell, U. \& Brownlee, C. 2010. Molecular mechanisms underlying calcification in coccolithophores. Geomicrobiol J. 27:585-95.

Mackinder, L., Wheeler, G., Schroeder, D., von Dassow, P., Riebesell, U. \& Brownlee, C. 2011. Expression of biomineralization-related ion transport genes in Emiliania huxleyi. Environ. Microbiol.. doi:10.1111/j.1462-2920.2011.02561.x.

Marsh, M. E. 1994. Polyanion-mediated mineralization - assembly and reorganization of acidic polysaccharides in the golgi system of a coccolithophorid alga during mineral deposition. Protoplasma 177:108-22.
Marsh, M. E. \& Dickinson, D. P. 1997. Polyanion-mediated mineralization-mineralization in coccolithophore (Pleurochrysis carterae) variants which do not express PS2, the most abundant and acidic mineral-associated polyanion in wild-type cells. Protoplasma 199:9-17.

Møller, J. V., Olesen, C., Winther, A.-M. L. \& Nissen, P. 2010. The sarcoplasmic $\mathrm{Ca}^{2+}$-ATPase: design of a perfect chemi-osmotic pump. Q. Rev. Biophys. 43:501-66.

Mortimer, C. 2003. Das Basiswissen der Chemie, 8th edn. Georg Thieme Verlag Stuttgart, Stuttgart.

Outka, D. E. \& Williams, D. C. 1971. Sequential coccolith morphogenesis in Hymenomonas carterae. J. Protozool. 18:285-97.

Paasche, E. 1962. Coccolith formation. Nature 193:1094-5.

Probert, I., Fresnel, J., Billard, C., Geisen, M. \& Young, J. R. 2007. Light and electron microscope observations of Algirosphaera robusta (Prymnesiophyceae). J. Phycol. 43:319-32.

Richier, S., Kerros, M. E., De Vargas, C., Haramaty, L., Falkowski, P. G. \& Gattuso, J. P. 2009. Light-dependent transcriptional regulation of genes of biogeochemical interest in the diploid and haploid life cycle stages of Emiliania huxleyi. Appl. Environ. Microb. 75:3366-9.

Schulz, K. G., Rost, B., Burkhardt, S., Riebesell, U., Thoms, S. \& Wolf-Gladrow, D. A. 2007. The effect of iron availability on the regulation of inorganic carbon acquisition in the coccolithophore Emiliania huxleyi and the significance of cellular compartmentation for stable carbon isotope fractionation. Geochim. Cosmochim. Ac. 71:5301-12.

Sekino, K. \& Shiraiwa, Y. 1994. Accumulation and utilization of dissolved inorganic carbon by a marine unicellular coccolithophorid, Emiliania huxleyi. Plant Cell Physiol. 35:353-61.

Sitte, P., Weiler, E. W., Kadereit, J. W., Bresinsky, A. \& Körner, C. 2002. Strasburger, Lehrbuch der Botanik, 35th edn. Spektrum Akademischer Verlag, Heidelberg, Berlin.

Soto, A. R., Zheng, H., Shoemaker, D., Rodriguez, J., Read, B. A. \& Wahlund, T. M. 2006. Identification and preliminary characterization of two cDNAs encoding unique carbonic anhydrases from the marine alga Emiliania huxleyi. Appl. Environ. Microb. 72:5500-11.

Staal, M., Elzenga, J. T. M. \& Prins, H. $1989 .{ }^{14}$ C fixation by leaves and leaf cell protoplasts of the submerged aquatic angiosperm Potamogeton lucens: carbon dioxide or bicarbonate? Plant Physiol. 90:1035

Sültemeyer, D. F., Miller, A. G., Espie, G. S., Fock, H. P. \& Canvin, D. T. 1989. Active $\mathrm{CO}_{2}$ transport by the green alga Chlamydomonas reinhardtii. Plant Physiol. 89:1213-9.

Sze, H., Liang, F., Hwang, I., Curran, A. C. \& Harper, J. F. 2000. Diversity and regulation of plant $\mathrm{Ca}^{2+}$ pumps: insights from expression in yeast. Ann. Rev. Plant Biol. 51:433-62.

Taylor, A. R., Chrachri, A., Wheeler, G., Goddard, H. \& Brownlee, C. 2011. A voltage-gated $\mathrm{H}^{+}$channel underlying $\mathrm{pH}$ homeostasis in calcifying coccolithophores. PLoS Biol. 9:1-13.

Volk, T. \& Hoffert, M. I. 1985. Ocean carbon pumps: analysis of relative strengths and efficiencies in ocean-driven atmospheric $\mathrm{CO}_{2}$ changes. In Sundquist, E. T. \& Broecker, W. S. [Eds.] The Carbon Cycle and Atmospheric $\mathrm{CO}_{2}$ : Natural Variations Archean to Present, vol. 32. AGU, Washington, DC, pp. 99-110.

van der Wal, L., de Bruijn, W. C. \& Westbroek, P. 1985. Cytochemical and X-ray microanalysis studies of intracellular calcium pools in scale-bearing cells of the coccolithophorid Emiliania huxleyi. Protoplasma 124:1-9.

van der Wal, P., de Jong, L., Westbroek, P. \& de Bruijn, W. C. 1983b. Calcification in the coccolithophorid alga Hymenomonas carterae. Ecol. Bull. 35:251-8.

van der Wal, P., de Jong, E. W., Westbroek, P., de Bruijn, W. C. \& Mulder-Stapel, A. A. 1983a. Ultrastructural polysaccharide localization in calcifying and naked cells of the coccolithophorid Emiliania huxleyi. Protoplasma 118:157-68.

Westbroek, P., de Jong, E. W., van der Wal, P., Borman, A. H., de Vrind, J. P. M., Kok, D., de Bruijn, W. C. \& Parker, S. B. 1984. Mechanism of calcification in the marine alga Emiliania huxleyi. Philos. T. Roy. Soc. B. 304:435-44. 
Wilbur, K. M. \& Watabe, N. 1963. Experimental studies on calcification in molluscs and the alga Coccolithus huxleyi. Ann. N.Y. Acad. Sci. 109:82-112.

Young, J. R. \& Westbroek, P. 1991. Genotypic variation in the coccolithophorid species Emiliania huxleyi. Mar. Micropaleontol. 18:5-23.

Young, J. R. \& Ziveri, P. 2000. Calculation of coccolith volume and its use in calibration of carbonate flux estimates. DeepSea Res. Pt. II 47:1679-700.

Zeebe, R. E. \& Wolf-Gladrow, D. A. 2001. $\mathrm{CO}_{2}$ in Seawater: Equilibrium, Kinetics, Isotopes. Elsevier Science Ltd., Amsterdam, pp. $1-346$.

Zuddas, P. \& Mucci, A. 1994. Kinetics of calcite precipitation from seawater: I. A classical chemical kinetics description for strong electrolyte solutions. Geochim. Cosmochim. Ac. 58: 4353-62.

\section{Supporting Information}

Additional Supporting Information may be found in the online version of this article at the publisher's web site:

Appendix S1. Appendix to kinetic model setup.

Figure S1. Model outputs to model version $\mathrm{Ib}$ and II. DIC in the cytosol was increased to $55 \mathrm{mmol} \cdot \mathrm{L}^{-1}$ in $\mathrm{Ib}$. Model version II is based on an active $\mathrm{CO}_{2}$ import into the $\mathrm{CV}$. Development of DIC, TA, $\Omega, \mathrm{Ca}^{2+}$ and the individual DIC species' concentrations inside the CV during the first $0.8 \mathrm{~s}$ of the model run.
Figure S2. Model outputs to model version IIIa. $\mathrm{Ca}^{2+}$ and $\mathrm{HCO}_{3}^{-}$cross the $\mathrm{CV}$ membrane independently of each other, while no $\mathrm{H}^{+}$are exported from the $\mathrm{CV}$.

Figure S3. Model outputs to version IV, Va, and Vb. $\mathrm{Ca}^{2+}$ and $\mathrm{CO}_{3}^{2-}$ are actively imported in version IV. Version $\mathrm{V}$ assumes an import of $\mathrm{Ca}^{2+}$, $\mathrm{HCO}_{3}^{-}$, and an export of $\mathrm{H}^{+}$, once via two transporters $(\mathrm{V}$ a) and once by means of one complex transporter $(\mathrm{V} \mathrm{b})$.

Figure S4. Results to model version VI. $\mathrm{Ca}^{2+}$ and $\mathrm{H}^{+}$cross the $\mathrm{CV}$ membrane actively, after a proton gradient across the $\mathrm{CV}$ membrane has been established by means of an ATPase. $\mathrm{CO}_{2}$ diffuses across the membrane in both stages.

Figure S5. Results to model version VII. $\mathrm{Ca}^{2+}$, $\mathrm{HCO}_{3}^{-}$, and $\mathrm{H}^{+}$actively cross the $\mathrm{CV}$ membrane, after the establishment of a proton gradient across the CV membrane by means of an ATPase. $\mathrm{CO}_{2}$ diffuses across the membrane in both stages. The plots on the left hand side present the whole model run, while on the right hand side, the time slot, during which the ATPase activity is stopped and the $\mathrm{Ca}^{2+} / \mathrm{HCO}_{3}^{-} / \mathrm{H}^{+}$exchanger starts its activity, is shown in more detail. 